\title{
PREFERENCE OF TEMORA STYLIFERA (CALANOID COPEPOD) FOR PLANKTONIC CILIATES AND EGG PRODUCTION
}

by

\author{
Ngurah N. Wiadnyana *\}
}

\begin{abstract}
The investigation of feeding and egg production of the calanoid co pepod Temora stylifera was carried out between September and November 1988. The copepods were fed on natural ciliates and phytoplankton assemblage. Planktonic ciliates composed of 2.20 to $3.83 \mathrm{~g} \mathrm{C} \mathrm{l}^{-1}$ representing 15.2 to $58.7 \%$ of total biomass in standing stock. They were consumed by these copepods at rates ranging from 11.25 to $38.14 \mathrm{~g} \mathrm{C} \mathrm{mg} \mathrm{DW}^{-1}$ $\mathrm{d}^{-1}$ or about 27.6 to $74.8 \%$ of total food consumed. The increase of ciliates/phytoplankton biomass ratio in the food consumed by the copepods in the all experiments indicates the preference for ciliates, in which as a good quality of food they can improve the rates of copepods egg production.
\end{abstract}

\section{INTRODUCTION}

Successful reproduction of planktonic crustaceans requires the efficient and coordinated utilizations of metabolic resources. The observation that zooplankton graze microplanktonic ciliates (Turner \& Anderson 1983. Stoecker \& Sanders 1985; Stoecker \& Egloff 1987; Robertson 1983; Wiadnyana \& Rassoulzadegan 1989) could be due to motility, greater size or nutritional quality of these preys. It is doubtful that motility and size alone drive feeding selectivity. It now is well known that copepods are capable of eating a wide range of cell sizes and shapes (Poulet 1973; Price et al. 1983), but active selection for larger cell size has not been demonstrated (Frost 1980). By contrast, feeding rate as well as fecundity and growth are affected by species of phytoplankton ingested (Mullin \& Brooks 1970). Moreover, higher ingestion rate by copepods for phytoplankton cells having low $\mathrm{C} / \mathrm{N}$ ratios also has been reported (Cowles et al. 1988), suggesting that nutritional quality of the food source is important. Therefore, both food quantity and quality have a strong influence on copepod reproduction (Checkley 1980; Cowles et al. 1988) The degree to which microplanktonic ciliates provide nutritional requirements $o$ marine copepods has not been fully explored.

*) BALITBANG Sumberdaya Laut., PUSLITBANG Oseanologi - LIPI 
Ciliates are quantitatively an importance and potential source of food for planktonic crustaceans in coastal and oceanic waters because of their abundance and size distribution. They have been estimated to account for 20 to $50 \%$ of the biomass available in the plankton of 20 to 200 size range (Stoecker \& Capuzo 1990).

In general, ciliates are larger in size than the algae or bacteria they eat. Much of the bacterial and phytoplankton production occurs in cells $<4-6 \mu \mathrm{m}$ in size (Sherr et al. 1986). Cells smaller than 4-6 $\mu \mathrm{m}$ are not efficiently grazed by most crustacean plankton (Nival \& Nival 1976) and thus microzooplanktonic ciliates are thought to be an important link between "microbial" production and crustacean zooplankton (Conover 1982 :Sherr et al. 1986). Almost all the ciliates are large enough to be efficiently grazed by most crustacean zooplankton.

In order to understand the role of planktonic ciliates in marine food webs, we need to consider the preference of zooplankton for ciliates, the contribution of these organisms in the diet of their consumers and the nutritional requirements of zooplankton fed on ciliate preys.

\section{MATERIAL AND METHODS}

In the study of the feeding and fecundity in zooplankton. Six time series of experiments were done between September and November 1988 by using the calanoid copepod Temora stylifera Dana. Copepods were collected by using plankton net $\left(0.28 \mathrm{~mm}\right.$ mesh size) from the surface coastal waters of the Mediterranean $\mathrm{N}-\mathrm{W}$, France $\left(43^{0}\right.$ $4^{\prime} 10^{\prime \prime} \mathrm{N}, 7^{\circ} 19^{\prime} 0^{\prime \prime} \mathrm{E}$ ). Fresh zooplankton was kept in a 101 polycarbonate bottle, Sea water, containing ciliates (loricate and aloricate ciliates) and phytoplankton assemblages, was sampled by using a Niskin bottle and poured onto 201 polycarbonate bottle. Zooplankton and sea water samples were immediately transported to the laboratory. Adults of female, Temora stylifera, were then gently isolated by pipette and placed in 5-liter glass jar, containing sea water and acclimated for about $6 \mathrm{~h}$ to allay the organisms. Seawater utilized in the experiment was filtered through a $100 \mu \mathrm{m}$ mesh to remove unknown predators by using an inverse screening device (Sheldon \& Rassoulzadegan 1987).

Experiments were conducted using 1 liter cylinder flexis-glass placed into inside each glass jar. Group of 5 female (total $0.24 \mathrm{mg}$ dry weight) Temora stylifera in ripe reproductive stages were kept in each cylinder containing sea waters that were screened with $200 \mu \mathrm{m}$ mesh to prevent the predation of copepods on eggs (Yassen 1984). 
Four experimental jars and two controls were incubated in a dark chamber at $17^{\circ} \mathrm{C}$ constant temperature for $24 \mathrm{~h}$ period. Samples of $200 \mathrm{ml}$ were taken in the beginning and last of the experiment and preserved with Lugol's iodine solution (Throndsen 1978). The remain of samples was concentrated by a sieve of $30 \mu \mathrm{m}$ mesh until $50 \mathrm{ml}$ aliquotes for egg counting. Before cell enumeration, samples were kept in a dark preservation chamber at $4^{\circ} \mathrm{C}$ temperature to avoid the cell damage due to the Lugol discoloration.

Eggs and cell numbers counting from 50 and $100 \mathrm{ml}$ aliquotes were done under an inverted microscope after settled in the Utermohl chamber for $>12$ hours (Rassoulzadegan \& Gostan 1976). Beside of cell enumeration, the biovolume of microplankton was measured also to estimate the wet weight biomass. Carbon biomass was found by multiplying wet weight biomass to the coefficient of Putt \& Stoecker (1989) for ciliates (0.19) and Wiadnyana \& Da Silva (Unpubl.) for phytoplankton (0.046 for diatoms and 0.134 for dinoflagellates). Specific ingestion rate was calculated using equation of Marin et al. (1986).

\section{RESULTS}

The calanoid copepod, Temora stylifera DANA, was exposed to mixtures of natural microplanktonic ciliates and phytoplankton (diatom and dinoflagellates) assemblages. These microplanktonic organisms provided as foods varied in both abundance and composition (Table I). The aloricate ciliates of size $10 \mu \mathrm{m}, 30$ $\mu \mathrm{m}, 30 \times 50 \mu \mathrm{m}$, and 40 x $60 \mu \mathrm{m}$ occured always in the experiments. Tintinnids (loricate ciliates) occurred only in experiment V and VI, and composed of a low contribution to the standing stock. Total standing stock of aloricate ciliates and tintinnids represented 13.2 to $54.2 \%$ and 2.1 to $6.6 \%$ respectively. The phytoplankton taxa as l.eptocylindrus. danicus, Rhizosolenia spp (large diatoms) and Rhiz.osolenia stolterforthii fairly occurred and were predominant diatoms, ranging from 0.8 . to $12.4 \%$, 1.4. to $4.2 \%$ and 1.9 . to $11.5 \%$ respectively. Various species of peridiniales (dinoflagellates) occurred in the experiments. The dinoflagellates: Ceratium furca (2.3. to 14.5\%), Gyrodinium spirale (1.0. to 6.0\%), Helgolandicus subglobosum (0.9 to 3.0\%), Protocentrum micans (0.4. to 3.2\%) and Protoperidinium pyriforme (2.9. to 5.6\%) were always found in the experiments. A large dinoflagellate, Pyrophacus horologicum was dominant in carbon standing stock at range from 26.0 to $36.6 \%$ when it was occurred.

Total numbers of cells ranged from $2.43 \times 10^{3}$ to $1.05 \times 10^{4}$ cells $1^{-1}$.The available biomass formed about 4.26

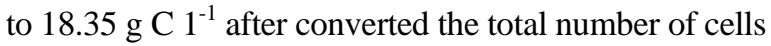


(ciliates + phytoplankton) to total carbon. Total ciliates (aloricate ciliates + tintinnids) and phytoplankton (diatoms + dinoflagellates) carbon ranged from 2.20 to 3.83.g C $1^{-1}$ (15.2 to $58.7 \%$ of total carbon) and

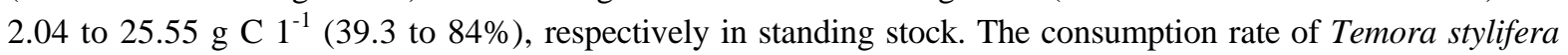
was 11.25 to $38.14 \mathrm{~g} \mathrm{C} \mathrm{mg} \mathrm{DW}^{-1} \mathrm{~d}^{-1}$ (27.6 to $74.8 \%$ ) for ciliates and 8.40 to $69.05 \mathrm{~g} \mathrm{C} \mathrm{mg} \mathrm{DW}^{-1} \mathrm{~d}^{-1}$ (25.2 to 72.4\%) for phytoplankton.

Daily rates of total carbon consumed by the copepods were 19.65 to $95.11 \mathrm{~g} \mathrm{C} \mathrm{mg} \mathrm{DW}^{-1}$ and eggs produced varied from 430.7 to 1058.6 eggs $\mathrm{mg} \mathrm{DW}^{-1}$ (19 to 58 eggs female ${ }^{-1} \mathrm{~d}^{-1}$ ). Results, in detail, were out lined in Table II.

Higher total ingestion of ciliates than phytoplankton was shown by ciliates (CIL) carbon/phytoplankton (PHY) carbon ratio (Fig. 1) The ingestion ratios increased largely in the all six experiments, where initial carbon of CIL : PHY ratios were near to 1 , excepted in the experiment III, where phytoplankton dominated the carbon standing stock (84.8\%).

The rates of copepod egg production were positively correlated to the proportion of ciliates in the food consumed by the copepods (Fig. 2). The results presume that the egg production of copepods increases 8,1 to $20,2 \%$ (average $=14,8 \%$ ) with increasing about $10 \%$ of ciliates consumed by the copepods.

\section{DISCUSSION}

Fecundity studies in copepods fed on natural foods, have been reported previously to determine the relationship between the egg production and total foods ingested (Ambler 1985). Such investigation on the food consumption of natural plankton assemblages, however, excluded planktonic ciliates (oligotrichous ciliated and loricate tintinnids) that were, furthermore, important in carbon standing stock (15 to $59 \%$ reported in this study). The difficulty of technique (Gifford 1985; Choi \& Stoecker 1989) is probably the raison to not observe these planktonic components.

Our specific observations on natural assemblages of planktonic ciliates different to those realized by Turner \& Tester (1989), revealed the selective feeding of the copepods on ciliates (Stoecker \& Sanders 1985; Sheldon et al. 1986; Wiadnyana \& Rassoulzadegan 1989). The exiting of a such behavior is supported by the fact that the ciliates/phytoplankton biomass ratios determined in food ingested by the copepods increase and reach the values higher to those of ciliates/phytoplankton biomass ratios observed in the environment (Fig. 1). A such preference of the copepods 
for the ciliates seems to be the consequence of the attract direction angle of the latter's toward the ciliates (Jonsson \& Tiselius 1990). In fact, the ciliates constitute food nutrient rich in protein, amino acids and lipid (Claustre et al. 1988; Putt \& Stoecker 1989; Stoecker \& Capuzzo 1990; Verity \& Langdon (1984). Those elements might influence the feeding intensity of the copepods upon microzooplankton. Elsewhere, the preference of the copepods for the ciliates over the phytoplankton may be related to the nature chemically defavorable of the latter. The avoidance and rejection of certain phytoplankton preys (specially dinoflagellates) by zooplankton can be due to the toxicity of those preys (Huntley etal 1983; Stoecker et al. 1987; Uye \& Takamatsu 1990). Nevertheless, the phytoplanktonic species observed in the experiments seem to be not toxic (Tabel 1). Although the diatoms and dinoflagellates could constitute a food source for the copepods, they must be ingested at high rates, by the fact that their nutritional value is relatively poor than the plank tonic ciliates \{Claustre et al. 1988; Putt Stoecker 1989; Verity \& Langdon 1984) Besides, the ciliates have carbon/cell volume ratios higher (0.19; Putt \& Stoecker 1989) than those of the phytoplankton (diatoms = 0.05 and dinoflagellates $=0.13$ Strathmann 1967).

Even if disregarding the other factors for copepod reproduction (Landry 1978; Uye 1981; Ambler 1985; Ianora et al. 1989), this study shows that the quality of food strongly influences the copepod egg production. Evidence that the copepod consumed more carbon of ciliates than phytoplankton. Temora stylofera seems increase its consumption on ciliates carbon in its diets compared to phytoplankton carbon (Fig. 1). Similar results are shown by Gifford \& Dagg (1988) for Acartia tonsa. A determination of the ratios of ciliates carbon: phytoplankton carbon consumed by the copepods (Fig. 1) might be used as an indication to prove the important nutritional value of ciliates in the diet of the copepod.

At the concentrations of natural environment, the copepod T. Stylifera appears to enhance its egg production with ingesting preferentially on the ciliates. In fad the copepods increase their egg production (15\%) with increasing about $10 \%$ of ciliates in their food consumed (Fig. 2). The results are comparable to those reported by (Stoecker \& Egloff 1987), in Acartia Tonsa. The enhancement of the fecundation in copepods proves high nutritional quality of the ciliates as food for the planktonic microcrustacean (Stoecker \& Egloff 1987). Indeed, Klepper et al. (1991) found that the variability of the number of eggs produced by the copepods seems to be independent of the variation phytoplantonic biomass, but this variability is affected by the biomass of microzooplankton ciliates in the waters. It might explain the rapid consummation of the microplankton in other groups of zooplanktonic consumers as well as in some zooplankton gelatinous (Pomeroy et al. 1987). 
In Laboratory, the copepod nauplii can grow on phytoplanktonic foods ( Harris \& Peffenhofer 1976). Since the quality of this food is inferior to those of microzooplanktonic ciliates (Claustre et al. 1988; Verity \& Langdon 1984), the larvae and young copepods must require a much quantity of phytoplankton to assure their survival and growth. In temperate region, important bloom of the phytoplankton occurs just in the spring, and then the larva survival out of this period would be supported by microplanktonic preys that occur in all the seasons (Rassoulzadegan 1982) as suggested by Sorokin (1978), who constated that microzooplankton (including ciliates ) may be a major food source and main alternative food for zooplankton. In a number of studies, it has remarked the importance of microzooplanktonic preys to certain life history stages of planktonic invertebrates and fish larvae (Cetta \& Capuzzo 1982; Stoecker et al. 1987).

In conclusion, we observed that: (i) the ciliates appear to be a source of preferred food for the copepods, and (ii) this preference allow an efficient assimilation of the microzooplankton food, since the productivity is clearly improved.

\section{LITERATURE CITED}

Ambler, J.W., 1985 Seasonal factors affecting egg production and viability of eggs of Acartia tonsa Dana from East Lagoon, Galveston, Texas. Estuar. Coast. Shelf Sci 20 : 743-760.

Cetta, C.M. \& J.M. Capuzzo, 1982. Physiological and biochemical aspect of embryonic and larval development of the winter flounder Pseudopleuronectes americanus. Mar Biol. 327-337.

Checkley, D. M. Jr. 1980 Food limitation of egg production by a marine planktonic copepod in the sea off southern California, Limnol. Oceanogr. 25 : 991-998.

Choi, J.W. \& D.K. Stoecker, 1989. Effect of fixation on cell volume of marine planktonic protozoa. Appl. Environ. Microbiol, 55 : 1761 - 1765.

Claustre, H.J., C. Marty, L. Cassiani \& J. Dagaut, 1988. Fatty acid dynamics in phytoplankton and microzooplankton communities during a spring bloom in the coastal Ligurian Sea. Mar. Microb. Food. Webs, 3 : 51-66.

Conover, R.J., 1982. Interrelations between microzooplankton and other plankton organisms. Ann. Inst. Oceanogr., Paris, 58 (S): 31-46.

Cowles, T.J., R. J. Olson \& S.W. Chisholm 1988. Food selection by copepods: dicrimation on the basis of food quality. Mar. Biol., 100: 41-49.

Frost, B.W., 1980. Grazing In : I Morris (ed) The Physiological Ecology of Phytoplankton. I., Blackwell Scientific. p. 465-491.

Gifford, D.J. 1985. Laboratory culture of marine planktonic oligotrichs (Ciliophora Oligotrichida). Mar. Ecol. Prog. Ser., 23: 257-267. 
Gifford, D. J. \& M. J. Dagg 1988. Feeding of the estuarine copepod Acartia tonsa Dana: carnivory vs. herbivory in natural microplanktonic assemblages. Bull Mar. Sci 42: 458-468.

Harris, R.P. \& G.A. Paffenhofer 1976. Feeding, growth and reproduction of the marine planktonic copepod Temora longicornis Muller. J. Mar. Biol. Ass. U.K. 56:675-690.

Huntley, M.E.K., G. Barthel \& J.L. Star, 1983. Particle rejection by Calanus pasificus : discrimination between similarly sized particles. Mar. Biol., 74: 151-160.

Ianora, I., B. Scotto di Carlo \& P. Mascellaro, 1989. Reproductive biology of the planktonic copepod Temora stylifera. Mar. Biol. 101: 187-194.

Jonsson P.R. \& P. Tiselius 1990. Feeding behaviour prey detection and capture efficiency of the copepod Acartia tonsa feeding on planktonic ciliates. Mar. Ecol Prog. Ser., 69:35-44.

Kleppel G.S., D.V. Holliday \& R.E. Pie^er 1991. Trophic interaction between copepod and microplankton : A question about role of diatoms. Limnol Oceanogr., 36: 172-179.

Landry, M.R. 1978. Population dynamics and production of a planktonic marine copepod, Acartia clausi, in a small temperate lagoon on San Juan Island, Washington. Int. Rev. Ges. Hyodrobiol. 63 : 77-119.

Marin, V., M.E. Huntley \& B. Frost 1986. Measuring feeding rates of pelagic herbivores: analysis of experimental design and methods. Mar. Biol. 93: 49-58.

Mullin, M.M. \& E.R. Brooks 1970. Growth and metabolism of two planktonic marine copepod as influenced by temperature and type of food. In : J.H. Steele (ed). Marine Food Chains. Oliver and Boyd, Edinburgh p. 74-95.

Nival, P. \& S. Nival 1976. Particle retention efficiencies of an herbivore copepod, Acartia clausi (adult and copepodite stages). Limnol. Oceanogr. 21: 25-49.

Pomeroy, L.R., G. A. Paffenhofer \& A.J. Yoder 1987. Summer upwelling on the southeastern continental shelf of the USA during 1981. Interaction of phytoplankton, zooplankton and microorganisms. Prog. Oceanogr., 19: 353-372.

Poulet, S.A. 1973. Grazing of Pseudocalanus minutus on naturally occuring particulate mater. Limnol. Oceanogr. 18: 564-573.

Price, C.A., G.A. Paffenhofer \& J.R. Striskler 1983. Modes of cell capture in calanoid copepod. Limnol. Oceanogr, 28: 116-123.

Putt, M \& D.K. Stoecker 1989. An experimentally determined carbon volume ratio for marine : oligotrichous ciliates from estuarine and coastal waters. Limnol. Oceanogr. 34: 1097-1103.

Rassoulzadegan, F 1982. Le fonctionnel du microzooplankton dans un ecosysteme mediterraneen. Thesis doktoral Univ. Paris VI., 350 pp. 
Rassoulzadegan, F \& J. Gostan 1976. Repatition des cili'es pelagiques dans des e'chantillons dans les eaux de ViUefranche-sur-Mer. Remarques sur la dispo-sion du microplankton en mer et a l'interieur des echantillosn denombres par la methode d'Utermohl. Ann. Inst. Oceanogr. Paris 52: 175-188.

Robertson, J.R. 1983. Predation by estuarine zooplankton on tintinnid ciliates. Estuar. Coast. shelf. Sci. 16: 27-36.

Sheldon, R.W. \& F. Rassoilzadegan 1987. A method for measuring plankton production by particle counting. Mar. Microb. Food Webs 2: 29-44.

Sheldon, R.W., P. Nival \& F. Rassoulzadegan 1986. An experimental investigation of a flagellate-ciliatecopepod food chain with some observations relevant to the linear biomass hypothesis. Limnol. Oceanogr., 31: 188.

Sherr, E.B., B.F. Sherr \& G.A. Paffenhofer 1986. Phagotrophic protozoa as food for metazoa : a "missing" trophic link in marine pelagic food webs. Mar. Microb. Food. Webs, 1: 61-80.

Stoecker, D.K. \& J. Mc. D. Capuzzo 1990. Predation on protozoa: Its importance to zooplankton. J. Plankton Res., 12: 891 - 908.

Stoecker, D.K. \& D.A. Egloff 1987. Preadation by Acartia tonsa Dana on planktonic ciliates and rotifers. J.Exp. Mar. Biol. Ecol. 110: 53-68.

Stoecker, D.K. \& N.K. Sandres 1985. Differential grazing by Acartia tonsa on a dinoflagellate and a tintinid J. Plankton Res 7 85-100.

Stoecker, D.K., A.E. Michaels \& L.H. Davis 1987. Grazing by the jellytish. Amelia aurita on a tintinnid $J$. Plankton Res., 9: 901-915.

Sathmann, R.R. 1967. Estimating the organic content of phytoplankton from cell volume of plasma volume. Limnol. Oceanogr, 12: 411-418.

Turner, J.T. \& D.M. Anderson 1983. Zooplankton grazing during dinoflagellate blooms in a Cape Cod Embayment, with observation of predation upon tintinnids by copepod P.S.Z.N.I Mar. Ecol. 4: 359374.

Turner, J.T. \& P.A. Tester 1989. Zooplankton feeding ecology : nonselective grazing by the copepods Acartia tonsa Dana., Centropoges relificatus De Oliveira, and Eucalanus pileatus Giesbrecth in the plume of the Mississippi River. J. Exp. Mar. Biol. Ecol. 1126: 21-43.

Thronsend, J. 1987. Preservation and storage. In : Sournia A. (ed) Phytoplankton manual. Monogr. Oceanogr. 6, UNESCO, p. 69-74.

Uye, S. 1981. Fecundity study of neritic calanoid copepods Acartia clausi Giesbrecth and A Steuri Sminov. : a simple emperical model of daily egg production, J. Exp. Mar. Biol. Ecol. 50: 255-271.

Uye, S. 1990. Feeding interactions between planktonis copepod and redtide flagellates from Japanese coastal waters. Mar. Ecol Prog. Ser., 59: 97-107. 
Verity, P.G. \& C. Langdon, 1984. Relationships between lorica volume, carbon, nitrogen and ATP content of tintinnids in Narragansett Bay, J. Plankton Res., 6: 859-868.

Wiadnyana, N.N., \& F. Rassoulzadegan 1989. Selective feeding of Acartia clausi and Centropages typicus on microzooplankton, Mar. Ecol. Prog. Ser. 53: 37-45.

Yaseen, S.T. 1984. Competition entre trois especes de copepodes planctoniques enelevage : Euterpina acutifrons, Temora Stylifera, Acartia clausi. Etudo' ecophysiologiques Ph.D. thesis Univ. P.et. M. Curie (Paris VI), 161 pp. 
Table I. Relative abundace (\%) of predominant plankton observed in the grazing and egg production experiments of Temora stylifera from Spetember to November 1988:I (14.09); II (27.09); III (28.09) IV (25.10); V (07.11). SAC and CAC $=$ spherical and conical aloricate ciliates, $\mathrm{CV}=$ cell biovolume.

Group/taxon

\begin{tabular}{rcccccc} 
CV & \multicolumn{7}{c}{ Experiment } \\
$(\mu \mathrm{m} 3)$ & I & II & III & IV & V & VI \\
$600 \cdot$ & 0.48 & 0.77 & 0.26 & 0.03 & 0.20 & 0.22 \\
8200 & & & & & 5.69 & 4.23 \\
11200 & 6.30 & 4.60 & 2.37 & 7.40 & & 23.68 \\
14100 & 1.32 & 5.02 & 0.38 & 3.11 & 2.30 & 1.45 \\
14500 & 17.67 & 33.76 & 6.01 & 9.18 & & 2.99 \\
21000 & 2.76 & 2.88 & 1.70 & 4.63 & 12.00 & 2.06 \\
32700 & 9.20 & 7.17 & 2.50 & 8.10 & 17.35 & 3.37 \\
79200 & & & & & 6.46 & \\
19850 & & & & & 1.22 & 0.61 \\
42500 & & & & & 4.16 & 1.31 \\
13830 & & & & & 1.18 & 0.21 \\
30000 & & & & & 0.59 &
\end{tabular}

10 um SAC

20 um SAC

8315

$\begin{array}{lll}0.11 & 0.58 & 0.10\end{array}$

$25 \times 30$ um CAC

$30 \mu \mathrm{m} \mathrm{SAC}$

$20 \times 40 \mu \mathrm{m} \mathrm{CAC}$

$30 \times 50 \mu \mathrm{m} \mathrm{CAC}$

3660

$\begin{array}{lll}12.39 & 2.28 & 4.86\end{array}$

$\begin{array}{ll}0.17 & 0.22\end{array}$

Leptoylindrus danicus Cleve

1280

Leptocylindrus minimus Gran

1500

0.01

Navicula sp.

120000

$2.37 \quad 3.00$

Nitzschia closterium (Ehr.)

95

Nitzschia delicatissima Cleve

338

$0.03 \quad 0.01$

Nitzschia longissima Ralfs

270

0.01

Nitzschia seriata Cleve

1640

$$
\begin{array}{lll}
0.50 \quad 0.07 \quad 0.18
\end{array}
$$

Pleurosigma angulatum

(Quekett)

11780

0.35

Rhizosolenia spp.

5800

$\begin{array}{lllll}4.21 & 3.46 & 1.71 & 1.55 & 1.43\end{array}$

Rhaizosolenia stolterforthii

Perag.

22200

$\begin{array}{llll}7.15 & 1.91 & 6.49 & 11.54\end{array}$

0.28

Thalassionema nitcshiodes

Grup. . 
Thalassionema nitcshiodes

Grun.

$0.68 \quad 0.43$

Ceratium furca (Ehr) Clap. et Lachm.

$\begin{array}{lllllll}63450 & 2.94 & 9.81 & 14.51 & 4.93 & 7.31 & 2.31\end{array}$

Ceratium fusus (Ehrbg.)

26225

$2.27 \quad 1.91$

Ceratium tripos (Mull) Nitcsch 147500

$\begin{array}{lll}3.90 & 2.85 & 1.87\end{array}$

6.37

Dinophysis acuta Ehr.

65000

3.72

Dinophsis spp.

25300

3.64

Gyrodium spirale (Bergh)

Kof. U. Swizy

$\begin{array}{lllllll}24000 & 0.95 & 6.03 & 2.59 & 1.86 & 2.42 & 1.75\end{array}$

Katodinium sp.

8200

$\begin{array}{lll}0.80 & 0.94 & 1.79\end{array}$

Helgolandicum subglobosum

Stosch

5000

1.7

2.992 .1

(2.13

$\begin{array}{lll}0.29 & 1.30 & 0.91\end{array}$

Minuscula bipes (Pauls) Lebour

2000

0.29

$0.17 \quad 0.07$

Oxytoxum scolcipax Stein

19680

Peridinium conicum, (Gran)

62200

$0.57 \quad 1.43$

Podolampas bipes Stein

41500

4.48

Podolampas spinifer (Pav)

11200

$2.39 \quad 1.51$

Prorocentrum micans Ehr.

8750

0.81

Protoperidnium pyriforme Pauls 32150

$\begin{array}{llllll}0.35 & 3.21 & 0.78 & 0.59 & 1.01 & 0.64\end{array}$

Pyrophacus horologicum Stein 335000

$\begin{array}{llllll}4.89 & 5.59 & 5.0(0) & 5.31 & 3.70 & 2.92\end{array}$

29.79

36.55 


\begin{tabular}{|c|c|c|c|c|c|c|c|}
\hline \multirow[t]{2}{*}{ Group/taxon } & \multirow{2}{*}{$\begin{array}{r}C V \\
(u m 3)\end{array}$} & \multicolumn{2}{|c|}{ Experiment } & \multirow{2}{*}{ III } & \multirow[b]{2}{*}{ IV } & \multirow[b]{2}{*}{$V$} & \multirow[b]{2}{*}{$V I$} \\
\hline & & $I$ & II & & & & \\
\hline \multicolumn{8}{|l|}{ Ceratium furca (Ehr) Clap. } \\
\hline et Lachm. & 63450 & 2.94 & 9.81 & 14.51 & 4.93 & 7.31 & 2.31 \\
\hline Ceratium fusus (Ehrbg.) & 26225 & & & & 2.27 & 1.91 & \\
\hline Ceratium tripos (Mull) Nitcsch & 147500 & 3.90 & 2.85 & 1.87 & & 6.37 & \\
\hline Dinophysis acuta Ehr. & 65000 & & & $3.72^{\circ}$ & & & \\
\hline Dinophsis spp. & 25300 & & & & 3.64 & & \\
\hline \multicolumn{8}{|l|}{ Gyrodium spirale (Bergh) } \\
\hline Kof. U. Swizy & 24000 & 0.95 & 6.03 & 2.59 & 1.86 & 2.42 & 1.75 \\
\hline Katodinium sp. & 8200 & & & & 0.80 & 0.94 & 1.79 \\
\hline \multicolumn{8}{|l|}{ Helgolandicum subglobosum } \\
\hline Stosch & 5000 & 1.72 & 2.99 & 2.13 & 0.29 & 1.30 & 0.91 \\
\hline Minuscula bipes (Pauls) Lebour & 2000 & & & 0.29 & & 0.17 & 0.07 \\
\hline Oxytoxum scolapax Stein & 19680 & & & & & 0.57 & 1.43 \\
\hline Peridinium conicum, (Gran) & 62200 & & & & & 4.48 & \\
\hline Podolampas bipes Stein & 41500 & & & & & 2.39 & 1.51 \\
\hline Podolampas spinifer (Pav) & 11200 & & & & & 0.81 & \\
\hline Prorocentrum micans Ehr. & 8750 & 0.35 & 3.21 & 0.78 & 0.59 & 1.01 & 0.64 \\
\hline Protoperidnium pyriforme Pauls & 32150 & 4.89 & 5.59 & 5.000 & 5.31 & 3.70 & 2.92 \\
\hline Pyrophacus horologicum Stein & 335000 & & & 29.79 & & & 36.55 \\
\hline
\end{tabular}

Table II. Summary of microplankton carbone standing stock and consumed by copepods Percentage in parenthese.

\begin{tabular}{lccl} 
I & $.3 .83(49.5)$ & $3.90(50.5)$ & 7.73 \\
II & $3.76(58.7)$ & $2.65(41.3)$ & 6.40 \\
III & $2.79(15.2)$ & $15.55(84.8)$ & 18.35 \\
IV & $3.05(51.1)$ & $2.93(48.9)$ & 5.98 \\
V & $2.36(53.7)$ & $2.04(46.4)$ & 4.39 \\
VI & $2.20(51.8)$ & $2.05(48.2)$ & 4.26 \\
\multicolumn{4}{c}{ Specific Ingestion Rate $(\mu \mathrm{g} \mathrm{C} / \mathrm{mg} \mathrm{DW} / \mathrm{d})$} \\
\end{tabular}

